\title{
Vitamin D was not associated with survival or cerebrospinal fluid cathelicidin levels in children with bacterial meningitis
}

\section{Savonius, Okko}

2018-12

Savonius , O , Pelkonen , T, Roine , I, Viljakainen , H, Andersson , S , Fernandez , J , Peltola , H \& Helve , O 2018 , ' Vitamin D was not associated with survival or cerebrospinal fluid cathelicidin levels in children with bacterial meningitis ' , Acta Paediatrica, vol. 107 , no. 12 , pp. 2131-2136 . https://doi.org/10.1111/apa.14393

http://hdl.handle.net/10138/306641

https://doi.org/10.1111/apa.14393

publishedVersion

Downloaded from Helda, University of Helsinki institutional repository.

This is an electronic reprint of the original article.

This reprint may differ from the original in pagination and typographic detail.

Please cite the original version. 


\section{Vitamin D was not associated with survival or cerebrospinal fluid cathelicidin levels in children with bacterial meningitis}

Okko Savonius (okko.savonius@helsinki.fi) ${ }^{1}$ (D), Tuula Pelkonen', Irmeli Roine ${ }^{2}$, Heli Viljakainen ${ }^{1,3}$, Sture Andersson', Josefina Fernandez ${ }^{4}$, Heikki Peltola', Otto Helve ${ }^{1}$ iD

1.Children's Hospital, Helsinki University Hospital, University of Helsinki, Helsinki, Finland

2.Medical Faculty, University Diego Portales, Santiago, Chile

3.Folkhälsan Research Centre, Helsinki, Finland

4.Clínica Infantil Dr. Robert Reid Cabral, Santo Domingo, Dominican Republic

\section{Keywords}

Bacterial meningitis, Cathelicidin, Immunity, Neurological sequelae, Vitamin D deficiency

\section{Correspondence}

O Savonius, Children's Hospital, Helsinki University Hospital, Stenbäckinkatu 11, 00290 Helsinki, Finland.

Tel: +358-45-6731185 |

Fax: +358-9-47176762

Email: okko.savonius@helsinki.fi

\section{Received}

15 December 2017; revised 11 April 2018; accepted 3 May 2018.

DOI:10.1111/apa. 14393

\begin{abstract}
Aim: Vitamin D deficiency impairs the immunological system and has been associated with worse outcomes of infectious diseases, but its role in bacterial meningitis remains unknown. We investigated whether serum 25-hydroxyvitamin D concentrations related to disease outcomes and to cerebrospinal fluid (CSF) cathelicidin concentrations in childhood bacterial meningitis.

Methods: All consecutively enrolled patients in a clinical trial on childhood bacterial meningitis in Latin America in 1996-2003 were considered, and 142 children, with a median age of seven months who had a confirmed bacterial aetiology and frozen serum available for further analyses, were included in this study. Serum 25-hydroxyvitamin D concentrations were determined with a chemiluminescence immunoassay analyser, while CSF cathelicidin was measured by enzyme-linked immunosorbent assay.
\end{abstract}

Results: The median serum 25-hydroxyvitamin D concentration was 96 (range 19-251) $\mathrm{nmol} / \mathrm{L}$. No relationship was found with patient survival, but children with any neurological sequelae had lower serum 25-hydroxyvitamin D levels than children without sequelae. Serum 25-hydroxyvitamin D was unrelated to cathelicidin concentrations in CSF.

Conclusion: Although serum 25-hydroxyvitamin D in children with bacterial meningitis was not associated with survival or CSF cathelicidin concentrations, its relationship with more detailed disease outcomes warrants further study.

\section{INTRODUCTION}

Vitamin D is well known for its vital role in bone homeostasis, but it also exerts multiple functions in the immune system (1). For example, it directly promotes the gene expression of the antimicrobial peptide cathelicidin (LL-37) by activating the vitamin $\mathrm{D}$ receptor, best documented in macrophages and monocytes (2-4). In general, vitamin $\mathrm{D}$ seems to shift the immune response towards a more tolerogenic state, acting through cells in both the innate and the adaptive immune systems (1).

Convincing data exist on the role of vitamin $\mathrm{D}$ in the host defence against Mycobacterium tuberculosis. Dating back to the pre-antibiotic era, tuberculosis was successfully treated with cod liver oil supplements and sunshine therapy (5-7). Vitamin D deficiency was later associated with increased mortality and risk of sepsis in critically ill adults $(8,9)$, as well as with an increased rate of respiratory tract infections (10). However, the effect of vitamin D

\section{Abbreviations}

CSF, Cerebrospinal fluid; IQR, Interquartile range; S-25-OHD, Serum 25-hydroxyvitamin D. supplements on the occurrence and outcomes of infectious diseases seems less clear $(11,12)$.

Vitamin D-deficient mice with induced bacterial meningitis died earlier than those with higher vitamin $\mathrm{D}$ levels (13). As the mice with higher vitamin D levels released more anti-inflammatory interleukin-10 and less pro-inflammatory interleukin-6, it raises the question about whether vitamin $\mathrm{D}$ would have a regulatory function in the immune response to bacterial meningitis? This question is even

\section{Key notes}

- The relationship between vitamin $\mathrm{D}$ with cerebrospinal fluid (CSF) cathelicidin and the disease outcomes in children with bacterial meningitis remains unknown.

- Our study of 142 children with bacterial meningitis showed a median serum 25-hydroxyvitamin D concentration of $96 \mathrm{nmol} / \mathrm{L}$, which did not relate to patient survival or CSF cathelicidin levels.

- Surviving children with any neurological sequelae had lower serum 25-hydroxyvitamin D levels compared to children without sequelae. 
more relevant, as the extent of the host reaction in bacterial meningitis is probably pivotal in the outcomes of this disease. One study reported that vitamin D deficiency in microglial cultures unexpectedly resulted in a decreased release of interleukin-6, a reduced phagocytosis and the reduced ability of cells to kill bacteria (14). In a clinical setting, vitamin D deficiency did not relate to the development or fungal clearance of cryptococcal meningitis (15), but its role in bacterial meningitis remains unstudied.

This contradictory information encouraged us to clarify the role of vitamin D in childhood bacterial meningitis, and we hypothesised that vitamin $\mathrm{D}$ might relate to disease outcomes. We therefore compared the serum 25-hydroxyvitamin D (S-25-OHD) concentrations in children with bacterial meningitis to different outcomes of the disease. We also investigated whether S-25-OHD correlated with cathelicidin levels in cerebrospinal fluid (CSF).

\section{PATIENTS AND METHODS}

Our group conducted a large prospective and double-blind treatment trial on childhood bacterial meningitis in Latin America from 1996 to 2003, focusing on the effects of adjuvant dexamethasone and glycerol (16). In the participating centres, all consecutive patients with suspected bacterial meningitis aged from two months to 16 years were assessed for eligibility. CSF was collected on admission to hospital and 12-24 hours later, whereas the serum samples were collected on admission and later if clinically required. This study included the patients with an aetiologically confirmed bacterial meningitis and frozen serum samples that could be used to determine S-25-OHD levels. The study protocol was approved by the ethics committees of all the study hospitals (16).

The patients' presenting clinical conditions were evaluated using the Glasgow Coma Scale, while their nutritional status was evaluated in terms of weight for age and converted to Z-scores according to World Health Organization standards. Severe neurological sequelae included blindness, quadriplegia or quadriparesis, severe psychomotor retardation or hydrocephalus requiring a shunt, while any neurological sequelae also comprised milder neurological findings such as monoparesis or hemiparesis, ataxia and moderate psychomotor retardation. Hearing deficits were not included in these definitions.

Special attention was paid to hearing impairment. At discharge from hospital, all children were tested, each ear separately, using traditional or brainstem evoked response audiometry. Deafness was defined as a bilateral hearing threshold of at least 80 decibels, and the audiological outcome was further assessed as the sum of the hearing threshold of both ears. Moreover, the patients were categorised using the hearing of the better ear into five ordinal categories. Finally, the summary outcome was graded using the Glasgow Outcome Scale.

Serum 25-hydroxyvitamin D was analysed using the fully automated immunoassay IDS-iSYS system (Immunodiagnostic Systems, Tyne and Wear, UK) with chemiluminescence detection with an intra-assay variation of less than 5\%. The IDS-iSYS system has shown a good linear agreement with liquid chromatography in tandem with mass spectrometry $\left(\mathrm{R}^{2}=0.942\right)$ based on an in-house comparison performed with 67 samples. The quality and accuracy of the S-25-OHD analysis are validated on an ongoing basis by participation in the Vitamin D External Quality Assessment Scheme, which is coordinated by Charing Cross Hospital, London, UK. The method has showed a 3\% positive bias against all laboratory trimmed mean values and a $10 \%$ positive bias compared with National Institute of Standards and Technology standards in international comparisons (17). It has been noted that there has been a minor tendency to overestimate the actual concentration.

If two or more serum samples were available, the mean value of the S-25-OHD concentration was taken into account. The patient's vitamin D status was examined by using both the continuous S-25-OHD concentration and the S-25-OHD concentration when it was categorised into groups: S-25-OHD concentrations of less than $50 \mathrm{nmol} / \mathrm{L}$ were defined as deficient and more than $125 \mathrm{nmol} / \mathrm{L}$ were regarded to be excessive (18). In addition, a cut-off value of $75 \mathrm{nmol} / \mathrm{L}$ was used to examine the potential beneficial effects of higher S-25-OHD levels (19). The cathelicidin concentrations had previously been assessed by enzymelinked immunosorbent assay in the CSF of a subgroup of patients, using the commercially available Human LL-37 ELISA Kit (Hycult Biotech, Uden, the Netherlands) (20).

In all, 142 children (59\% male) were included in the study, with a median age of seven months. They originated from Santo Domingo in the Dominican Republic $(\mathrm{n}=85)$, Guayaquil in Ecuador $(\mathrm{n}=41)$ and Barquisimeto in Venezuela $(\mathrm{n}=16)$. The causative agents of their bacterial meningitis were Haemophilus influenzae type $\mathrm{b}(\mathrm{n}=81)$, Streptococcus pneumoniae $(\mathrm{n}=43)$, Neisseria meningitidis $(\mathrm{n}=9)$, Salmonella spp. type $\mathrm{D}(\mathrm{n}=5)$, Streptococcus agalactiae $(\mathrm{n}=2)$ and Haemophilus influenzae type a $(\mathrm{n}=2)$. The patient characteristics are summarised in Table 1.

\section{Statistical methods}

The normality of variables was visually inspected. First, we compared S-25-OHD concentrations with the baseline patient characteristics. We then projected S-25-OHD concentrations against different disease outcomes, including death, occurrence of severe or any neurological sequelae, deafness, the hearing threshold measured at discharge and the outcome in terms of the Glasgow Outcome Scale score. Finally, we investigated whether the CSF cathelicidin concentrations on admission, or during treatment, were associated with S-25-OHD.

Statview software version 5.0.1 (SAS Institute, Cary, NC, USA) was used for the statistical analysis. Spearman's rank correlation, the Mann-Whitney $U$-test and the KruskalWallis test were used to compare the vitamin D levels with patient characteristics, disease outcomes and the CSF cathelicidin levels. The chi-square test was applied when we compared the categorical variables, while multivariate analyses were conducted with multiple regression analysis. 
$\mathrm{P}$ values of less than 0.05 were considered statistically significant, using the Bonferroni corrections in multiple comparisons.

Table 1 Patient characteristics

\begin{tabular}{|c|c|}
\hline Characteristic & Result \\
\hline Total number of patients & 142 \\
\hline Male sex (\%) & $84 / 142(59)$ \\
\hline Age, median months (IQR) & $7(5-13)$ \\
\hline Weight-for-age Z-score, median (IQR) & $-0.73(-1.7$ to 0.3$)$ \\
\hline GCS score on admission, median (IQR) & $13(10-14)$ \\
\hline \multicolumn{2}{|l|}{ Aetiology, number of cases } \\
\hline Haemophilus influenzae & 81 \\
\hline Streptococcus pneumoniae & 43 \\
\hline Neisseria meningitidis & 9 \\
\hline Other & 9 \\
\hline Prior antimicrobial treatment (\%) & $57 / 129(44)$ \\
\hline \multicolumn{2}{|l|}{ CSF test results on admission } \\
\hline Leucocyte count, median cells/ $\mu \mathrm{L}$ (IQR) & $2500(920-6500)$ \\
\hline Polymorphonuclear cells, percentage (IQR) & $77.5(56-87)$ \\
\hline Protein level, median mg/dL (IQR) & $163(87-249)$ \\
\hline Glucose level, median mg/dL (IQR) & $15.5(9-31)$ \\
\hline \multicolumn{2}{|l|}{ Blood test results on admission } \\
\hline White cell count, median $10^{3}$ cells/ $\mu \mathrm{L}$ (IQR) & $13.5(8.8-19.2)$ \\
\hline Haemoglobin level, median g/dL (IQR) & $8.2(7.3-9.3)$ \\
\hline Glucose level, median mg/dL (IQR) & $104.5(81-136)$ \\
\hline Sodium level, median mmol/L (IQR) & $137(135-141)$ \\
\hline GOS score at discharge, median (IQR) & $4(3-5)$ \\
\hline
\end{tabular}

$\mathrm{CSF}=$ Cerebrospinal fluid; GCS = Glasgow Coma Scale; GOS = Glasgow Outcome Scale. $I Q R=$ Interquartile range

\section{RESULTS}

\section{Serum vitamin $D$ levels and baseline characteristics}

The analyses were based on 142 patients. The median S-25OHD concentration was $96 \mathrm{nmol} / \mathrm{L}$, with an interquartile range (IQR) of $80-119 \mathrm{nmol} / \mathrm{L}$ : five patients $(4 \%)$ had S-25-OHD levels below $50 \mathrm{nmol} / \mathrm{L}$, while the vitamin D concentration exceeded $125 \mathrm{nmol} / \mathrm{L}$ in 31 patients $(22 \%)$ (Fig. 1). Deficient vitamin D levels (S-25-OHD $<50 \mathrm{nmol} /$ L) were associated with younger patient age $(p=0.03)$, lower weight-for-age Z-scores $(p=0.02)$ and lower blood glucose levels on admission $(\mathrm{p}=0.005)$, while excessive S-25-OHD (>125 nmol/L) related to a lower CSF glucose on admission $(\mathrm{p}=0.03)$.

When we looked at S-25-OHD as a continuous variable, children from Ecuador showed significantly lower S-25OHD concentrations than children from Venezuela and the Dominican Republic ( $<0.001$; Fig. 2). Moreover, lower S-25-OHD related to a higher CSF glucose $(\rho=-0.197$, $\mathrm{p}=0.03)$ and a higher serum sodium level $(\rho=-0.199$, $\mathrm{p}=0.04)$ on admission. However, in a multivariate regression model with the country of origin, serum sodium level and CSF glucose, only the country of origin remained a significant predictor of S-25-OHD. No other associations between the vitamin $\mathrm{D}$ concentrations and the patient characteristics were found (Table 1).

\section{Serum vitamin D levels and disease outcomes}

The S-25-OHD concentration on admission did not relate to the child's survival $(\mathrm{p}=0.86)$, severe neurological sequelae $(p=0.85)$ or deafness $(p=0.25)$. Moreover, the S-25-OHD concentration was not associated with the

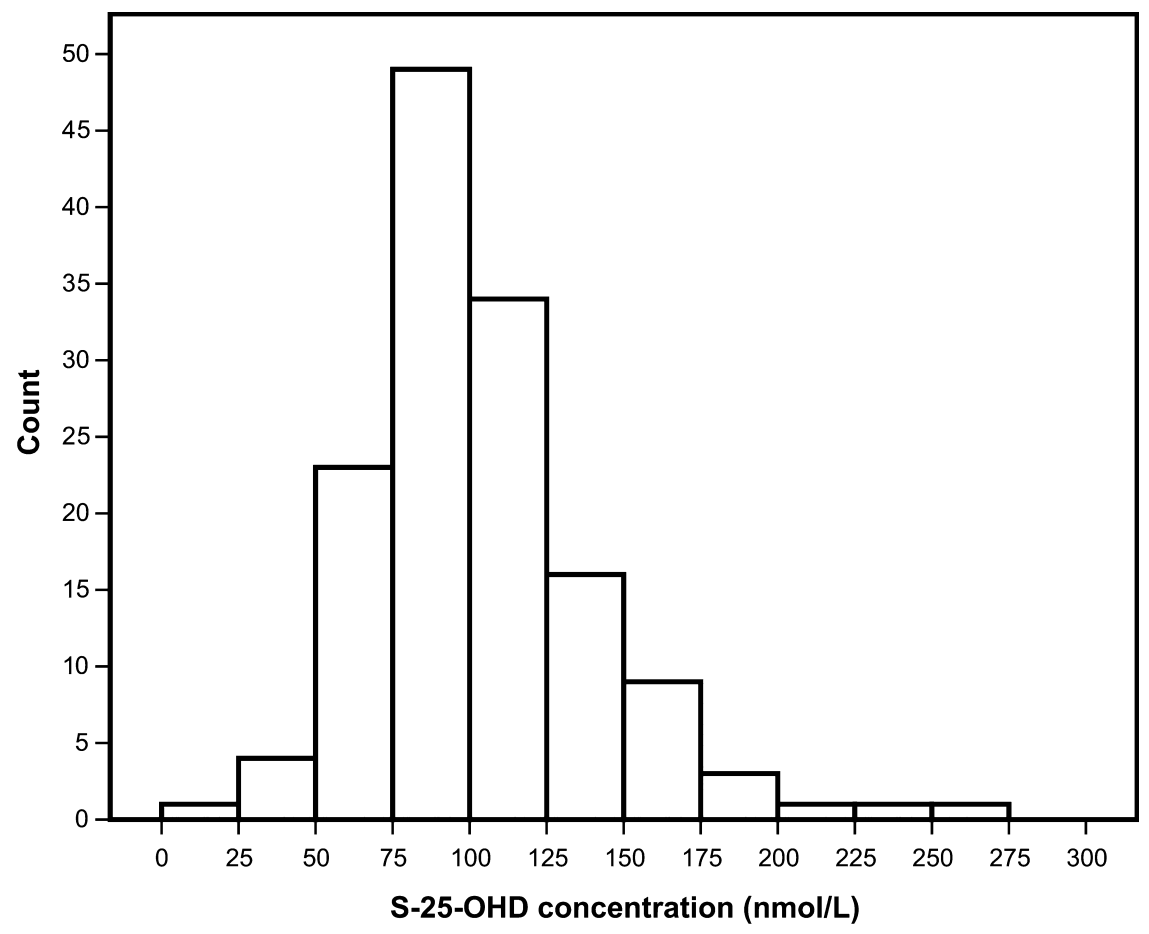

Figure 1 Serum 25-hydroxyvitamin D concentrations. 


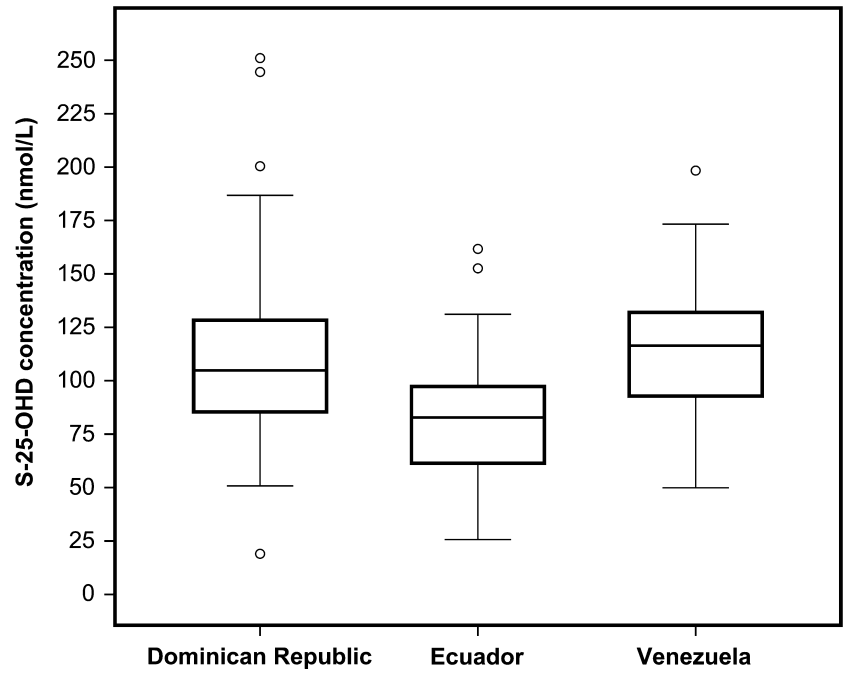

Figure 2 Serum 25-hydroxyvitamin $D$ concentrations according to country of origin. Kruskal-Wallis test, $\mathrm{p}<0.001$. Pairwise comparisons with Mann-Whitney $U$-test (Bonferroni-corrected $\mathrm{p}$ values): Ecuador versus Venezuela, $\mathrm{p}=0.01$; Ecuador versus Dominican Republic, $\mathrm{p}<0.001$; Venezuela versus Dominican Republic, $\mathrm{p}=1.0$. Data are presented as Tukey's box-and-whisker plots.

disease outcome in terms of the Glasgow Outcome Scale score $(\rho=-0.047, p=0.60)$. However, surviving children with any neurological sequelae had slightly lower S-25OHD concentrations than children without neurological sequelae: the median S-25-OHD concentration was $89 \mathrm{nmol} / \mathrm{L}$ (IQR 75-111) in children with any neurological sequelae, compared to $101 \mathrm{nmol} / \mathrm{L}$ (IQR 85-127) in children without sequelae $(\mathrm{p}=0.04)$.

A tendency for an inverse association between S-25OHD and hearing outcome was observed in 98 of the 119 survivors $(\rho=-0.176, p=0.08)$. In line with this, children with S-25-OHD below $75 \mathrm{nmol} / \mathrm{L}$ seemed to develop hearing problems to a lesser extent, in terms of the categorised hearing of the better ear $(\mathrm{p}=0.01)$. However, when information from both ears was combined, statistical significance was lost $(p=0.07)$. Deficient S-25-OHD did not relate to the audiological outcome $(\mathrm{p}=0.21)$.

\section{Serum vitamin $D$ and CSF cathelicidin}

The CSF cathelicidin concentration had previously been analysed in CSF in 115 samples taken at presentation and in 76 samples taken $12-24$ hours later. The median concentrations were $35.4 \mathrm{ng} / \mathrm{mL}$ (IQR 9.0-105.5) and $7.6 \mathrm{ng} / \mathrm{mL}$ (IQR 3.3-45.5), respectively. The S-25-OHD concentrations were not related to CSF cathelicidin in either sample: $\rho$ was -0.071 at presentation $(p=0.45)$ and was 0.010 after $12-24$ hours $(\mathrm{p}=0.93)$. In addition, the change in CSF cathelicidin during treatment did not relate to the S-25-OHD concentration.

\section{DISCUSSION}

Our study presents novel data on the vitamin D status of children with bacterial meningitis from Latin America and suggests that serum vitamin D concentrations were mainly sufficient and remained unassociated with patient survival. CSF cathelicidin was not related to serum vitamin D concentrations.

Based on the literature (8), we expected the vitamin D status to affect the prognosis of bacterial meningitis, but S-25-OHD was not associated with survival, severe neurological sequelae or deafness. The 40 surviving children with any neurological sequelae at discharge had slightly lower S25-OHD levels than the 75 children without sequelae, although the median S-25-OHD values were within the normal range in both groups. Interestingly, an inverse association was marked between S-25-OHD and the audiological outcome in survivors.

Previous reports on vitamin D in hearing impairment have shown inconsistent results. Vitamin D deficiency and hearing deficits were linked to an older study published in 1984, and vitamin D receptor knockout mice developed sensorineural hearing loss at an earlier age $(21,22)$. However, since then a Korean study has reported an association between higher serum vitamin $\mathrm{D}$ concentrations and worse hearing, and a study on mice exhibiting premature ageing syndrome demonstrated that a diet deficient in vitamin D prevented hearing loss $(23,24)$. Given these results, both insufficient and excessive serum vitamin $\mathrm{D}$ concentrations might contribute to the pathological processes that affect hearing.

Obviously, our finding of lower S-25-OHD concentrations relating to milder hearing impairment in children with bacterial meningitis needs further confirmation. The toxicity of higher S-25-OHD concentrations is not a possible explanation for this finding, as we found no correlation between excessive (>125 nmol/L) S-25-OHD and audiological outcomes. Nevertheless, as the role of vitamin D has not been previously investigated in this setting, the optimal S-25-OHD concentration in bacterial meningitis remains unknown.

We did not find any evidence to suggest that circulating vitamin D levels regulated CSF cathelicidin synthesis. One study reported a poor urine cathelicidin response in vitamin D-deficient patients with an acute urinary tract infection when they were compared with patients with higher serum vitamin D levels (25). Previous studies have also suggested a relationship between vitamin D and serum cathelicidin, although this association seemed to disappear when vitamin D levels were sufficient (26) Thus, given the rather high vitamin $\mathrm{D}$ concentrations in our patients, the lack of an association between vitamin $\mathrm{D}$ in serum and cathelicidin in CSF was not entirely surprising. Perhaps the vitamin D levels in our patients were sufficient to not impair the synthesis of cathelicidin in CSF.

Compared with previous reports from the same region, our patients showed surprisingly high serum vitamin D levels (27). The lower concentrations in children from Ecuador may be, at least partly, explained by geography, as the city of Guayaquil enjoys less sunshine each year than the other study centres in Santo Domingo in the Dominican Republic and Barquisimeto in Venezuela (28-30). The 
different ethnic origins of the population may also be an important factor, although the largest ethnic groups in all three countries seem to be mixed race. On the other hand, dissimilar regular supplements of vitamin D and differing dietary habits cannot be ruled out. We assume that these three Latin American countries were not profoundly dissimilar in these aspects of child health.

We acknowledge that our study had some limitations. This sample comprised a rather small group of children from Latin America, and the low prevalence of vitamin D deficiency may simply have been characteristic of the studied regions. As our series only included five patients with serum 25-OHD below $50 \mathrm{nmol} / \mathrm{L}$, conclusions on the role of vitamin $\mathrm{D}$ deficiency in the host response to bacterial meningitis should be made with caution. Previous studies have suggested a relationship between vitamin D levels and disease outcomes in critically ill adults, where poorer outcomes were associated with a concentration somewhere below $50 \mathrm{nmol} / \mathrm{L}$ (8.9). A similar cut-off value was also used in studies of respiratory tract infections (10). Whether such concentrations would relate to poorer outcomes in paediatric patients with bacterial meningitis remains unclear, but we hypothesise that a similar association might exist.

\section{CONCLUSION}

Altogether, our results suggest that vitamin D concentrations in children with bacterial meningitis from Latin America were mainly sufficient and were not related to either patient survival or CSF cathelicidin concentrations. However, the detected relationship between S-25-OHD and both neurological and audiological outcomes warrants further research to explore the impact of vitamin D on the host response and outcomes of this disease.

\section{ACKNOWLEDGEMENTS}

The authors thank Sari Lindén for excellent technical assistance and Claire Foley for language editing.

\section{FUNDING}

This work was supported by Stiftelsen Dorothea Olivia, Karl Walter och Jarl Walter Perkléns minne, Päivikki ja Sakari Sohlbergin säätiö, Lastentautien Tutkimussäätiö, Finska Läkaresällskapet, Special Governmental Subsidy for Clinic Research and Suomen Lääketieteen Säätiö.

\section{CONFLICT OF INTEREST}

The authors have no conflict of interests to declare.

\section{References}

1. Prietl B, Treiber G, Pieber TR, Amrein K. Vitamin D and immune function. Nutrients 2013; 5: 2502-21.
2. Gombart AF, Borregaard N, Koeffler HP. Human cathelicidin antimicrobial peptide (CAMP) gene is a direct target of the vitamin $\mathrm{D}$ receptor and is strongly up-regulated in myeloid cells by 1,25-dihydroxyvitamin D3. FASEB J 2005; 19: 1067-77.

3. Vandamme D, Landuyt B, Luyten W, Schoofs L. A comprehensive summary of LL-37, the factotum human cathelicidin peptide. Cell Immunol 2012; 280: 22-35.

4. Liu PT, Stenger S, Li H, Wenzel L, Tan BH, Krutzik SR, et al. Toll-like receptor triggering of a vitamin D-mediated human antimicrobial response. Science 2006; 311: 1770-3.

5. Nnoaham KE, Clarke A. Low serum vitamin D levels and tuberculosis: a systematic review and meta-analysis. Int J Epidemiol 2008; 37: 113-9.

6. Green M. Cod liver oil and tuberculosis. BMJ 2011; 343: d7505.

7. Roelandts R. The history of phototherapy: something new under the sun? J Am Acad Dermatol 2002; 46: 926-30.

8. de Haan K, Groeneveld AB, de Geus HR, Egal M, Struijs A. Vitamin D deficiency as a risk factor for infection, sepsis and mortality in the critically ill: systematic review and metaanalysis. Crit Care 2014; 18: 660.

9. Upala S, Sanguankeo A, Permpalung N. Significant association between vitamin $\mathrm{D}$ deficiency and sepsis: a systematic review and meta-analysis. BMC Anesthesiol 2015; 15: 84.

10. Science M, Maguire JL, Russell ML, Smieja M, Walter SD, Loeb M. Low serum 25-hydroxyvitamin D level and risk of upper respiratory tract infection in children and adolescents. Clin Infect Dis 2013; 57: 392-7.

11. Wejse C, Gomes VF, Rabna P, Gustafson P, Aaby P, Lisse IM, et al. Vitamin D as supplementary treatment for tuberculosis: a double-blind, randomized, placebo-controlled trial. Am J Respir Crit Care Med 2009; 179: 843-50.

12. Martineau AR, Jolliffe DA, Hooper RL, Greenberg L, Aloia JF, Bergman P, et al. Vitamin D supplementation to prevent acute respiratory tract infections: systematic review and metaanalysis of individual participant data. BMJ 2017; 356: i6583.

13. Djukic M, Sostmann N, Bertsch T, Mecke M, Nessler S, Manig A, et al. Vitamin D deficiency decreases survival of bacterial meningoencephalitis in mice. J Neuroinflammation 2015; 12: 208.

14. Djukic M, Onken ML, Schutze S, Redlich S, Götz A, Hanisch UK, et al. Vitamin D deficiency reduces the immune response, phagocytosis rate, and intracellular killing rate of microglial cells. Infect Immun 2014; 82: 2585-94.

15. Jarvis JN, Bicanic T, Loyse A, Meintjes G, Hogan L, Roberts $\mathrm{CH}$, et al. Very low levels of 25-hydroxyvitamin D are not associated with immunologic changes or clinical outcome in South African patients with HIV-associated cryptococcal meningitis. Clin Infect Dis 2014; 59: 493-500.

16. Peltola H, Roine I, Fernandez J, Zavala I, Ayala SG, Mata AG, et al. Adjuvant glycerol and/or dexamethasone to improve the outcomes of childhood bacterial meningitis: a prospective, randomized, double-blind, placebo-controlled trial. Clin Infect Dis 2007; 45: 1277-86.

17. Carter GD. Accuracy of 25-hydroxyvitamin D assays: confronting the issues. Curr Drug Targets 2011; 12: 19-28.

18. Ross AC, Manson JE, Abrams SA, Aloia JF, Brannon PM, Clinton SK, et al. The 2011 report on dietary reference intakes for calcium and vitamin D from the institute of medicine: what clinicians need to know. J Clin Endocrinol Metab 2011; 96: 53-8.

19. Holick MF, Binkley NC, Bischoff-Ferrari HA, Gordon CM, Hanley DA, Heaney RP, et al. Evaluation, treatment, and prevention of vitamin D deficiency: an Endocrine Society clinical practice guideline. J Clin Endocrinol Metab 2011; 96 : 1911-30. 
20. Savonius O, Helve O, Roine I, Andersson S, Fernández J, Peltola $\mathrm{H}$, et al. Swiftly decreasing cerebrospinal fluid cathelicidin concentration predicts improved outcome in childhood bacterial meningitis. J Clin Microbiol 2016; 54: 1648-9.

21. Brookes GB. Vitamin D deficiency and deafness: 1984 update. Am J Otol 1985; 6: 102-7.

22. Zou J, Minasyan A, Keisala T, Zhang Y, Wang JH, Lou YR, et al. Progressive hearing loss in mice with a mutated vitamin D receptor gene. Audiol Neurootol 2008; 13: 219-30.

23. Kang JW, Choi HS, Kim K, Choi JY. Dietary vitamin intake correlates with hearing thresholds in the older population: the korean national health and nutrition examination survey. Am J Clin Nutr 2014; 99: 1407-13.

24. Carpinelli MR, Wise AK, Burt RA. Vitamin D-deficient diet rescues hearing loss in klotho mice. Hear Res 2011; 275: 105-9.

25. Ovunc Hacihamdioglu D, Altun D, Hacihamdioglu B, Cekmez F, Aydemir G, Kul M, et al. The association between serum 25hydroxy vitamin $\mathrm{D}$ level and urine cathelicidin in children with a urinary tract infection. J Clin Res Pediatr Endocrinol 2016; 8: 325-9.
26. Dixon BM, Barker T, McKinnon T, Cuomo J, Frei B, Borregaard N, et al. Positive correlation between circulating cathelicidin antimicrobial peptide (hCAP18/LL-37) and 25hydroxyvitamin D levels in healthy adults. BMC Res Notes 2012; 5: 575.

27. Checkley W, Robinson CL, Baumann LM, Hansel NN, Romero KM, Pollard SL, et al. 25-hydroxy vitamin D levels are associated with childhood asthma in a population-based study in Peru. Clin Exp Allergy 2015; 45: 273-82.

28. World Wide Travel Organisation. Average monthly hours of sunshine in Barquisimeto. Available at: https://weather-andclimate.com/average-monthly-hours-Sunshine,Barquisimeto, Venezuela (accessed on April 4, 2017).

29. World Wide Travel Organisation. Average monthly hours of sunshine in Santo Domingo. Available at: https://weather-andclimate.com/average-monthly-hours-Sunshine,SantoDomingo,Dominican-Republic. (accessed on April 4, 2017).

30. World Wide Travel Organisation. Average monthly hours of sunshine in Guayaquil. Available at: https://weather-and-clima te.com/average-monthly-hours-Sunshine,guayaquil,Ecuador (accessed on April 4, 2017). 